\title{
Garcinol inhibits the proliferation of endometrial cancer cells by inducing cell cycle arrest
}

\author{
MIN ZHANG* , QINSHENG LU* , HUOMEI HOU, DINGQIAN SUN, MIAOJUAN CHEN, FEN NING, \\ PEIHUANG WU, DAN WEI, YAOYUN DUAN, YUE PAN and GENDIE E. LASH \\ Institute of Pediatrics, Guangzhou Women and Children's Medical Center, \\ Guangzhou Medical University, Guangzhou, Guangdong 510623, P.R. China
}

Received May 25, 2020; Accepted October 5, 2020

DOI: $10.3892 /$ or.2020.7900

\begin{abstract}
Endometrial cancer (EC) is the most common gynecological cancer, and one of the most important causes of cancer-related deaths in women worldwide. The long-term survival rate is lower in advanced-stage and recurrent EC, therefore it is important to identify new anticancer drugs. Garcinol, a polyisoprenylated benzophenone, is a promising anticancer drug for various cancer types but its effects on EC remain unclear. To investigate the anticancer effects of garcinol on EC, cell proliferation and cell cycle were assessed by real-time cell proliferation, cell counting, and colony formation assays, flow cytometric analysis, and 5-ethynyl-2'-deoxyuridine (EdU) incorporation assay, in EC Ishikawa (ISH) and HEC-1B cell lines. Western blotting was used to evaluate the expression of cell cycle-related protein cyclins, cyclin-dependent kinase and tumor suppression proteins. Garcinol inhibited ISH and HEC-1B cell proliferation in a dose-dependent manner, and induced ISH and HEC-1B cell cycle arrest at the G1 phase and G2/M phase, respectively, and decreased the $\mathrm{S}$ phase and DNA synthesis in these two cell lines. Following garcinol treatment the expression levels of p53 and p21 were increased, while the expression levels of CDK2, CDK4, cyclin D1 and cyclin B1 were gradually decreased in a dose-dependent manner in both ISH and HEC-1B cells. In addition, the expression levels of phosphorylated c-JUN $\mathrm{N}$-terminal kinase (JNK) and p-c-JUN were significantly increased in both types of cells. Collectively, garcinol can induce EC cell cycle arrest and may be a promising candidate for EC chemotherapy.
\end{abstract}

Correspondence to: Dr Gendie E. Lash, Institute of Pediatrics, Guangzhou Women and Children's Medical Center, Guangzhou Medical University, 9 Jinsui Road, Tianhe, Guangzhou, Guangdong 510623, P.R. China

E-mail: gendie.lash@hotmail.com

*Contributed equally

Key words: endometrial cancer, garcinol, proliferation, cell cycle, chemotherapy

\section{Introduction}

Endometrial cancer (EC) is the most common gynecological cancer in developed countries and one of the most important causes of cancer-related deaths in women worldwide. Approximately 3\% of women develop EC in their lifetime, and the incidence is expected to increase further over the next 10 years (1). EC is generally classified into two types. Type I $\mathrm{EC}$ is the most common and is estrogen-related, and in general this tumor is low grade and can be diagnosed according to early bleed symptoms. Type II EC is much more likely to be high grade (2). The survival rate of patients with early-stage $\mathrm{EC}$ is relatively high, but there is a poor prognosis for patients with advanced or recurrent EC due to limited treatment options (3). In addition, for patients with metastatic EC, the median survival time is only 7-12 months (4). The standard treatment for EC is surgery, platinum-based chemotherapy and radiotherapy where recommended as adjuvant therapy for patients with high histologic grade or metastasis (3). Estrogen and progesterone receptors are expressed in Type 1 EC, which is often responsive to endocrine treatment (5). However, endocrine therapy for advanced stage and recurrent EC remains controversial as it has not been revealed to widely improve long-term survival rates (6). For unresectable recurrent/metastatic EC, chemotherapy is vital for EC patients, but currently the options for therapeutic agents are limited, this may be in part due to variations in the molecular and genetic characteristics of the tumor. In addition, EC patients are presenting at a younger age than in previous decades (7-9) therefore more chemotherapeutic agents or individual targeting drugs with lower toxicity need to be urgently investigated. One option is to investigate potential therapeutic drugs from natural compounds to improve EC treatment.

Garcinol, a polyisoprenylated benzophenone, is a natural compound isolated from the fruit rinds of Garcinia indica (10). In recent years, garcinol has been reported to have antioxidative, anti-inflammatory and anticancer effects (11-14). The anticancer function of garcinol has been reported in several types of cancer cells, such as colon, prostate, liver, lung, breast, esophageal, pancreatic and oral cancer cells (12,15-18). Zhao et al demonstrated that garcinol suppressed cervical cancer cell proliferation but did not change the cell viability of primary normal cervical cells (19). Studies have also 
revealed that garcinol has an antitumor function in vivo and in vitro $(12,13)$. Therefore, garcinol may be a promising agent for some types of cancers. However, it has not been investigated whether garcinol has anticancer effects in EC.

The cell cycle is an important physiological process regulating cell growth and proliferation. Cell cycle progression is tightly controlled by cell cycle-related proteins, including cell cycle promotors cyclin D/E/A/B and cyclin-dependent kinase (CDK) 1/2/4/6, and cell cycle inhibitors p15, p16, p21, p27 and p53 (20). These proteins exert their functions at specific different phases of the cell cycle, although the cell cycle has a circular control system. Cyclins are synthesized and destroyed at particular times during the cell cycle (21). Different members of the CDK family are associated with different cyclins, which play an important role in switching from one phase to the next throughout the cell cycle (22). Numerous anticancer drugs induce cell cycle arrest to inhibit tumor cell proliferation (23-26). Studies have revealed that garcinol can also induce cell cycle arrest to inhibit cell growth in lung cancer (26), cervical (19), oral (24), and breast cancer (17). In lung cancer cells, garcinol altered relative cell-cycle protein expression levels, upregulating p53 and p21, and downregulating cyclin $\mathrm{D}, \mathrm{CDK} 2$ and $\mathrm{CDK} 4$, to induce cell cycle arrest (26). Garcinol inhibited cervical cancer cells by delaying cell cycle progression at the G0/G1 phase and downregulating cyclin D1 and CDK4, while upregulating p21 and p53 (19). However, whether garcinol can induce cell cycle arrest and inhibit cell proliferation in EC is unknown. Therefore, the aim of the present study was to investigate the effect(s) of garcinol on EC cell proliferation and the cell cycle.

\section{Materials and methods}

Cell culture. The human EC cell lines, Ishikawa (ISH) and HEC-1B, were purchased from FuHeng Cell Bank (FuHeng Biology; https://www.fudancell.com/). Both of these cell lines were authenticated with DNA fingerprinting using short tandem repeat (STR) methodology by the provider on 13 June 2017 and 24 May 2017, respectively. ISH and HEC-1B cells were cultured in RPMI-1640 medium (cat. no. SH30809; HyClone; Cytiva) with $10 \%$ fetal bovine serum (FBS) (cat. no. SFBS-B; Bovogen Biologicals Pty, Ltd.), 1\% penicillin-streptomycin (cat. no. 15140122, Gibco; Thermo Fisher Scientific, Inc.), and incubated in $5 \% \mathrm{CO}_{2}$ humidified atmosphere at $37^{\circ} \mathrm{C}$. The medium was changed every 2 days.

Real-time cell proliferation assay. The label-free real-time cellular analysis (RTCA) system (ACE BioSciences, Inc.) was used to observe the effect of garcinol on cell proliferation according to the manufacturer's instructions. Culture medium $(50 \mu \mathrm{l})$ was added to each well of a 16-well E-plate to plot the baseline prior to the addition of 5,000 cells in $100 \mu \mathrm{l}$ medium containing various concentrations of garcinol $(0,1,5,10$ and $20 \mu \mathrm{M}$; cat. no. 2088-25; BioVision, Inc.). The cells were placed at room temperature for $30 \mathrm{~min}$ to attach to the E-plate before subsequent detection. Cells were incubated in a $5 \% \mathrm{CO}_{2}$ humidified atmosphere at $37^{\circ} \mathrm{C}$ for $72 \mathrm{~h}$. The instrument recorded the impedance of the electron flow caused by adherent cells using a non-unit parameter called cell index. Data was recorded every $15 \mathrm{~min}$. The assay was performed in duplicate at least three times.
Cell counting assay. The cells $\left(1 \times 10^{5}\right)$ were seeded in 6-well plates. After incubation in a $5 \% \mathrm{CO}_{2}$ humidified atmosphere at $37^{\circ} \mathrm{C}$ for $24 \mathrm{~h}$, various concentrations of garcinol $(0,1,5,10$ and $20 \mu \mathrm{M}$ ) were added to each well and the cells were cultured in a $5 \% \mathrm{CO}_{2}$ humidified atmosphere at $37^{\circ} \mathrm{C}$. After $48 \mathrm{~h}$, the cells were digested at $37^{\circ} \mathrm{C}$ for $3 \mathrm{~min}$ by $0.25 \%$ trypsin-EDTA solution (cat. no. 25200056; Gibco; Thermo Fisher Scientific, Inc.) and resuspended to a single cell suspension, and then the number of cells were counted by an automated cell counter machine (Bio-Rad Laboratories, Inc.). The assay was performed three times in triplicate.

Colony formation assay. A total of 500 cells/well were plated in 6-well plates, after $24 \mathrm{~h}$, and then $0,1,5,10$ and $20 \mu \mathrm{M}$ garcinol was added and the media changed every $48 \mathrm{~h}$. After 14 days, the cells were washed with phosphate-buffered saline (PBS) and fixed with $100 \%$ methanol at room temperature for $30 \mathrm{~min}$, and then washed with PBS. The plates were stained with $1 \%$ crystal violet for $1 \mathrm{~h}$ at room temperature and washed with tap water. Plates were air-dried, photographed and all colonies were counted. The assay was performed three times in triplicate.

Western blot analysis. Control and garcinol-treated cells were washed twice with cold phosphate-buffered saline (PBS) and then RIPA buffer was added (cat. no. P0013B; Beyotime Institute of Biotechnology) with PMSF (cat. no. ST506; Beyotime Institute of Biotechnology) and protease inhibitor cocktail (cat. no. CW2383S; CWBIO) on ice. Cells were detached with a scraper, and cell suspensions were transferred to EP tubes and lysed on ice for $30 \mathrm{~min}$. Cell lysates were centrifuged at $12,000 \mathrm{x} \mathrm{g}$ at $4^{\circ} \mathrm{C}$ for $30 \mathrm{~min}$ and the supernatant was collected and stored at $-80^{\circ} \mathrm{C}$ until required for analysis. Protein concentrations were determined by BCA protein assay kit (cat. no. P0009; Beyotime Institute of Biotechnology). Total protein $(20 \mu \mathrm{g})$ was mixed with $5 \mathrm{X}$ loading buffer and denatured at $95^{\circ} \mathrm{C}$ for $8 \mathrm{~min}$ before being separated on $10 \%$ SDS-PAGE (cat. no. 1610183; Bio-Rad Laboratories) and electro-transferred onto polyvinylidene difluoride (PVDF) membranes (cat. no. IPVH00010; EMD Millipore). The membranes were blocked with 5\% skimmed milk for $2 \mathrm{~h}$ at room temperature and incubated with target antibodies on a shaking bed overnight at $4^{\circ} \mathrm{C}$. Primary antibodies used in the present study were: Anti-p53 (cat. no. MA5-12557; mouse; 1:1,000) and anti-cyclin D1 (cat. no. MA5-14512; rabbit; 1:800; both from Invitrogen; Thermo Fisher Scientific, Inc.); anti-cyclin B1 (cat. no. GB11255; rabbit; 1:1,000; from Servicebio); anti-p21 (product code ab109520; mouse; 1:2,000; Abcam); anti-CDK2 (cat. no. sc-6248; mouse; 1:2,000; Santa Cruz Biotechnology, Inc.); anti- $\beta$-actin (cat.no.A531; mouse; 1:5,000; Sigma-Aldrich; Merck KGaA); anti-SAPK/JNK (product no. 9252S; rabbit; 1:2,000); anti-c-JUN (product no. 9165S; rabbit; 1:1,000); phospho-SAPK/JNK (Thr183/Tyr185) (product no. 4668S; rabbit; 1:1,000); and phospho-c-JUN (Ser73) (product no. 3270S; rabbit; 1:1,000; all from Cell Signaling Technology, Inc.). After removing the primary antibodies, membranes were washed with TBST 3x10 min. The membranes were then incubated with HRP-conjugated secondary antibodies goat anti-rabbit IgG (H+L) (cat. no. SA00001-2; 1:5,000) and goat anti-mouse IgG (H+L) (cat. no. SA00001-1, 1:5,000; both from 

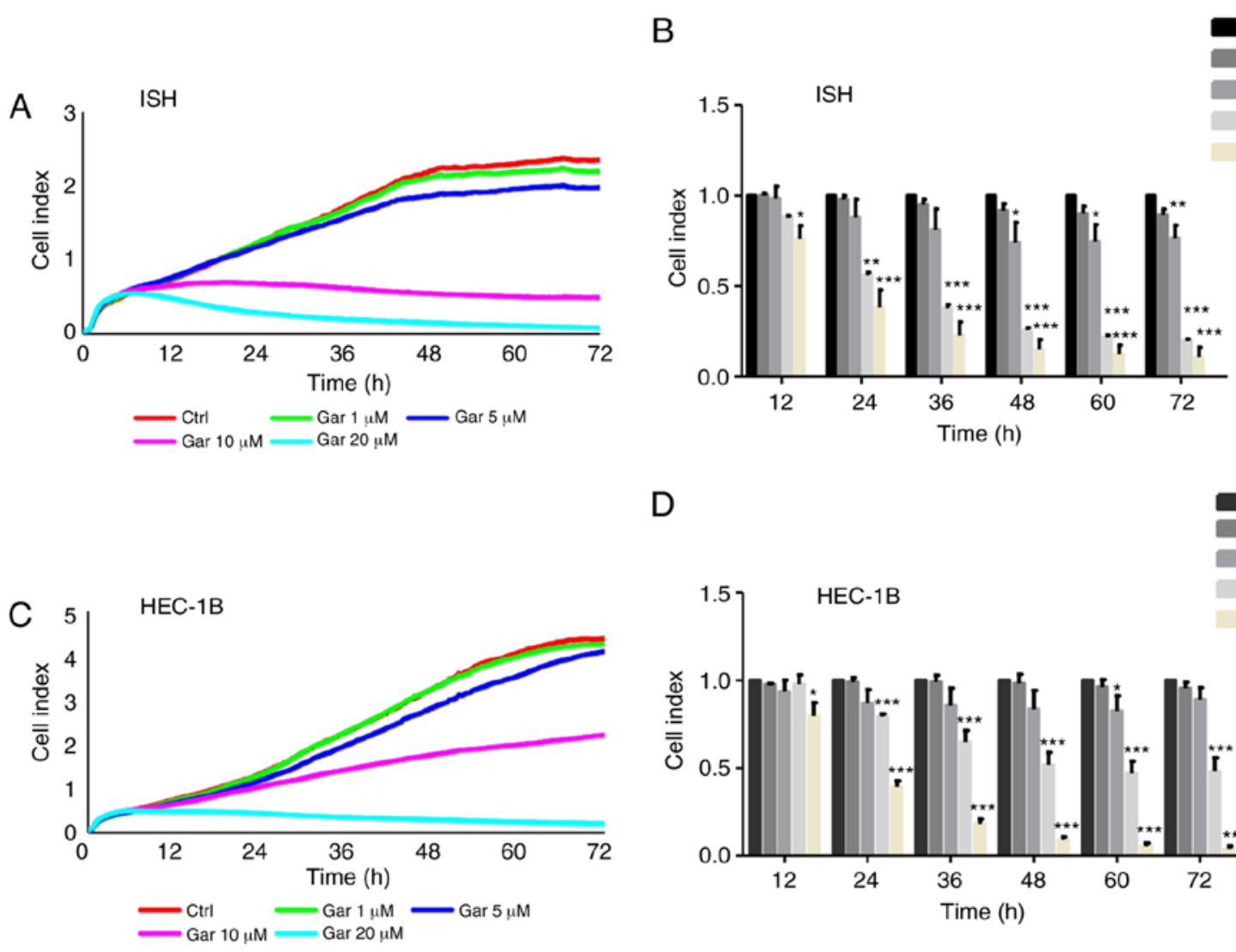

D
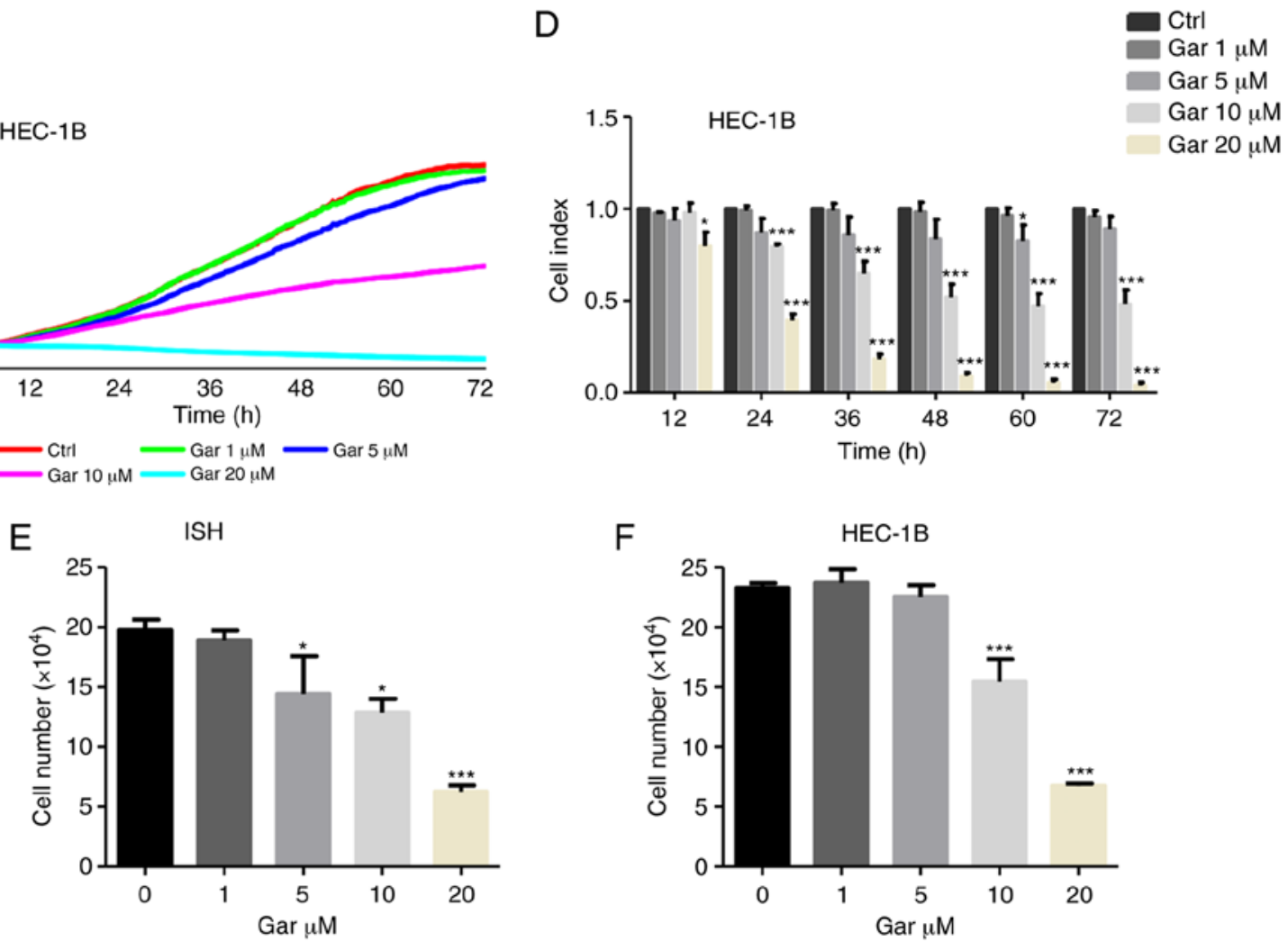

Figure 1. Garcinol inhibits the proliferation of EC cells. (A-D) Proliferation assays of EC (A and B) ISH cells and (C and D) HEC-1B cells, exposed to 0, 1, 5,10 and $20 \mu \mathrm{M}$ garcinol for $72 \mathrm{~h}$ and detected by label-free RTCA. Data are presented as cell index curves, which were recorded by the RTCA instrument for (A) ISH cells and (C) HEC-1B cells. Data at time-points 12, 24, 36, 48, 60 and $72 \mathrm{~h}$ were analyzed separately for (B) ISH cells and (D) HEC-1B cells (E and F) Cell counting results of (E) ISH cells and (F) HEC-1B cells, which were treated with garcinol $(0,1,5,10$ and $20 \mu \mathrm{M})$ for $48 \mathrm{~h}$. Data are presented as the mean $\pm \mathrm{SD}, \mathrm{n}=3 .{ }^{*} \mathrm{P}<0.05,{ }^{* *} \mathrm{P}<0.01,{ }^{* * *} \mathrm{P}<0.001$ as compared with the control group, indicate statistical significance by one-way ANOVA with Dunnett's multiple comparisons test. EC, endometrial cancer; ISH, Ishikawa; RTCA, real-time cellular analysis; Gar, garcinol.

ProteinTech Group, Inc.) on a shaking bed for $2 \mathrm{~h}$ at room temperature. After washing 3 times with TBST, chemiluminescence substrate was used for development and signals were captured by ChemiDoc XRS+ imaging system (Bio-Rad Laboratories, Inc.). Data were analyzed by ImageJ 1.45 software (NIH) and $\beta$-actin was used as the internal control. Each assay was repeated 3 times.

Flow cytometric analysis. ISH and HEC-1B cells were seeded at $5 \times 10^{5}$ cells in $60 \mathrm{~mm}$ dishes. After $24 \mathrm{~h}$, media with various concentrations of garcinol $(0,10$ and $20 \mu \mathrm{M})$ were added to cells to treat for $48 \mathrm{~h}$ at $37^{\circ} \mathrm{C}$. Cells were washed with PBS, digested to a single cell suspension with $0.25 \%$ trypsin-EDTA solution for $3 \mathrm{~min}$ at $37^{\circ} \mathrm{C}$, and then centrifuged at $200 \mathrm{x}$ g for
$5 \mathrm{~min}$ at room temperature to collect cells. After resuspension, cells were fixed with chilled $75 \%$ alcohol at $-20^{\circ} \mathrm{C}$ for 2 days. Cells were washed $3 \mathrm{x}$ with ice cold PBS, stained with propidium iodide (PI) $(50 \mu \mathrm{g} / \mathrm{ml})$ (cat. no. P4170) and RNase A $(100 \mu \mathrm{g} / \mathrm{ml})$ (cat. no. V900498; both from Sigma-Aldrich; Merck $\mathrm{KGaA}$ ) for $30 \mathrm{~min}$ at $37^{\circ} \mathrm{C}$ in the dark. A FACS Aria II flow cytometer (BD Biosciences) was used to obtain cell cycle data and data were analyzed by FLOWJO 7.6 (BD Biosciences).

Each experiment was repeated 3 separate times.

5-Ethynyl-2'-deoxyuridine (EdU) incorporation assay. Cells $\left(1.5 \times 10^{4}\right)$ were seeded in 8 -well Nunc Lab-Tek II chamber slides (cat. no. 154534; Thermo Fisher Scientific, Inc.) and treated with various concentrations of garcinol $(0,10$ and 


\section{$\operatorname{Gar}(\mu \mathrm{M})$}

1
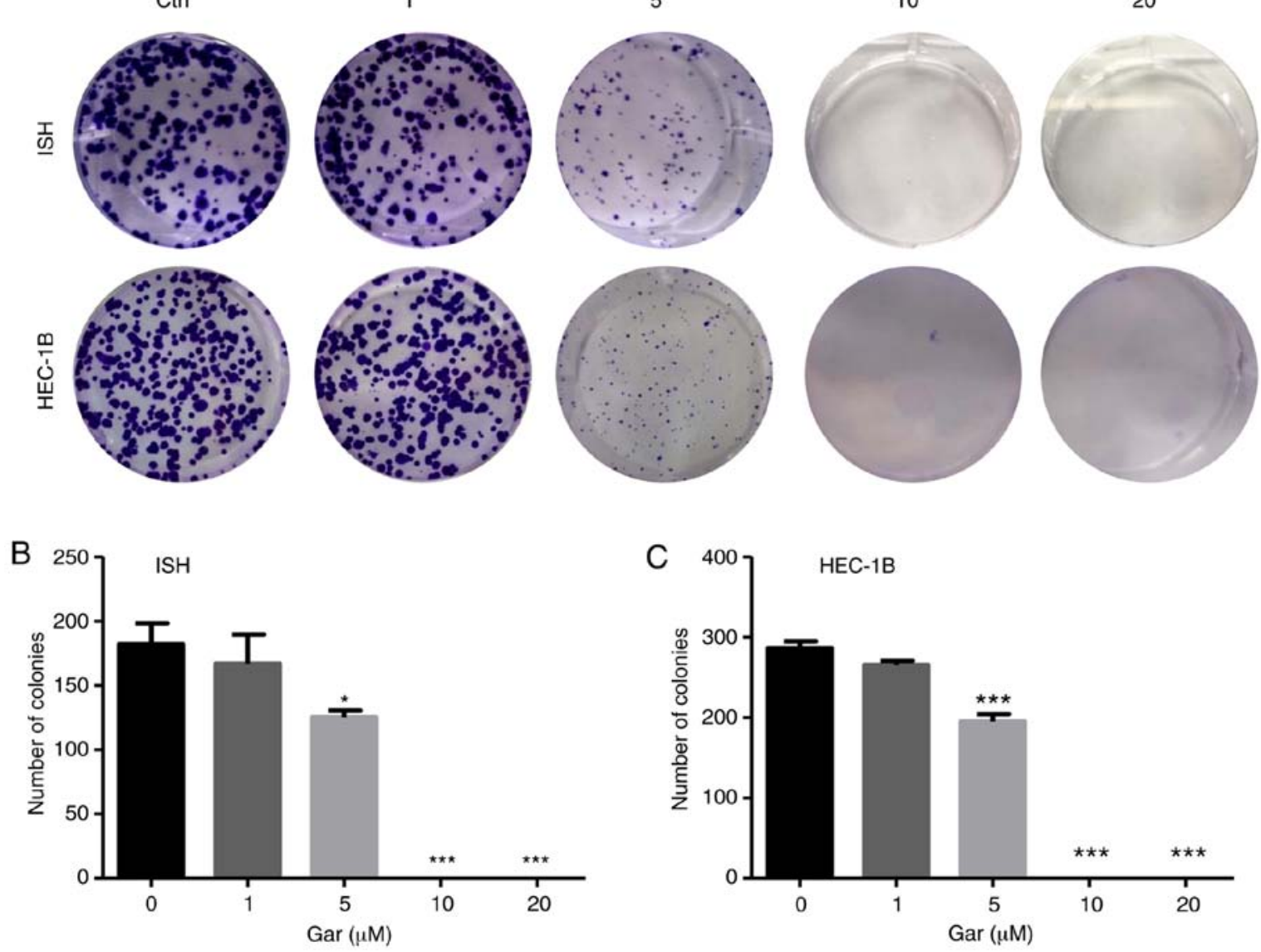

20
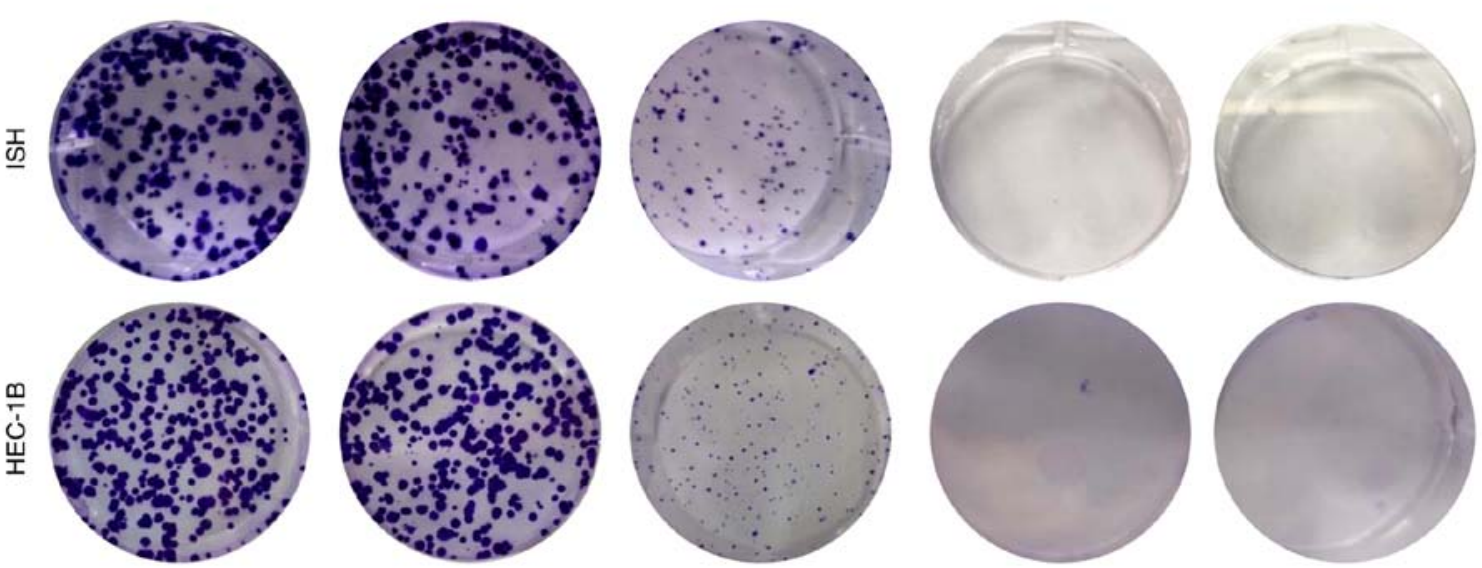

C $4007 \quad$ HEC-1B

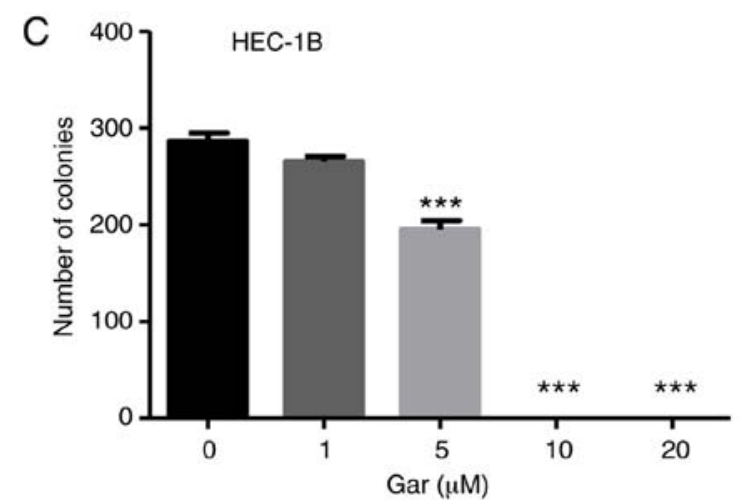

Figure 2. Garcinol inhibits colony formation of EC cells. ISH and HEC-1B cells were treated with garcinol $(0,1,5,10$ and $20 \mu \mathrm{M})$ for 14 days and stained with crystal violet. (A) Representative images of colony formation assay for ISH (upper panel) and HEC-1B (lower panel) cells. (B and C) The number of ISH (B) and HEC-1B (C) colonies in each of the treatment groups were counted and data is presented as the mean $\pm \mathrm{SD}, \mathrm{n}=3$. ${ }^{*} \mathrm{P}<0.05$ and ${ }^{* * *} \mathrm{P}<0.001$ compared with the control, indicate statistical significance by one-way ANOVA with Dunnett's multiple comparisons test. EC, endometrial cancer; ISH, Ishikawa; Gar, garcinol.

$20 \mu \mathrm{M})$ for $48 \mathrm{~h}$ at $37^{\circ} \mathrm{C}$ when $10 \mu \mathrm{M}$ EdU (BeyoClick ${ }^{\mathrm{TM}} \mathrm{EdU}$ Cell Proliferation Kit with Alexa Fluor 488; cat. no. C0071L, Beyotime, Shanghai, China) used according to the manufacturer's instructions was added to the cell culture and the cells were incubated for an additional $2 \mathrm{~h}$ at $37^{\circ} \mathrm{C}$. The cells were then fixed with $4 \%$ paraformaldehyde at room temperature for $30 \mathrm{~min}$, permeabilized with $0.3 \%$ Triton $\mathrm{X}-100$ for $15 \mathrm{~min}$, and then click additive solution contained in the aforementioned kit was added and the cells were incubated on a shaking bed for $30 \mathrm{~min}$ at $37^{\circ} \mathrm{C}$ in the dark. The cell nucleus was stained with Hoechst 33342 (included in the aforementioned kit) for $15 \mathrm{~min}$ at room temperature. Images were captured by Leica DM4B Fluorescence Microsystems using a 20X objective. Data are presented as the ratio of the fluorescent-positive cells to total cells. Each experiment was repeated 3 separate times.

Statistical analysis. Data are presented as the mean \pm standard deviations (SD). Statistical analysis was performed using the SPSS 16.0 (IBM Corp.). One-way analysis of variation (ANOVA) with Dunnett's multiple comparisons test was used to compare individual data with the control values. $\mathrm{P}<0.05$ was considered to indicate a statistically significant difference. All experiments were repeated at least three times.

\section{Results}

Garcinol inhibits EC cell proliferation. To investigate the effect of garcinol on EC proliferation, RTCA and a cell counting assay were performed with ISH and HEC-1B cells. In the RTCA assay, garcinol inhibited cell proliferation of both ISH and HEC-1B cells in a dose- and time-dependent manner (Fig. 1A-D). This result was confirmed in both cell lines by traditional cell counting methodology (Fig. 1E and F). Data revealed that ISH cells were more sensitive than HEC-1B cells to garcinol treatment, since $5 \mu \mathrm{M}$ garcinol could significantly inhibit cell proliferation in ISH cells from 48 to $72 \mathrm{~h}$, but that concentration of garcinol could only inhibit the proliferation of HEC-1B cells at $60 \mathrm{~h}$ (Fig. 1B and D).

Garcinol inhibits the colony formation ability of EC cells. After 14 days of continuous culture in various concentrations of garcinol, colony formation of both ISH and HEC-1B cells was significantly inhibited (Fig. 2). Treatment with $5 \mu \mathrm{M}$ garcinol resulted in fewer, smaller colonies in both cell lines compared with the control. Treatment with 10 and $20 \mu \mathrm{M}$ garcinol completely inhibited colony formation. However, even after a long culture time, $1 \mu \mathrm{M}$ garcinol could not significantly decrease the ability of colony formation in both types of cells. 
A
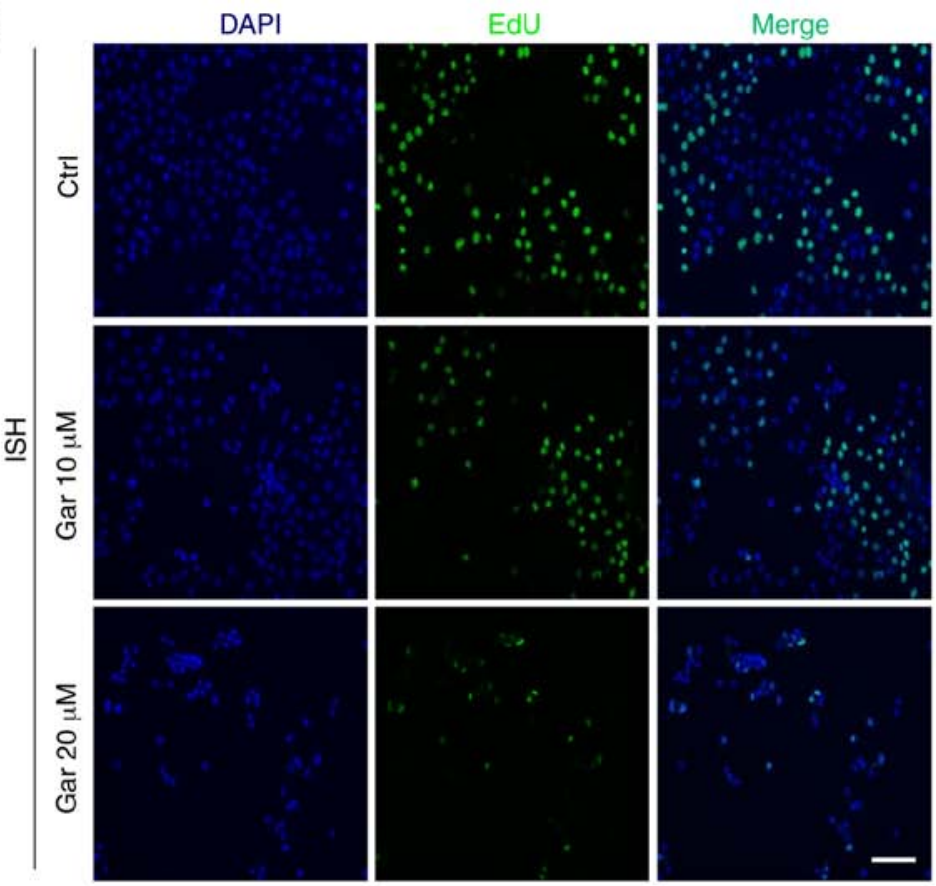

C

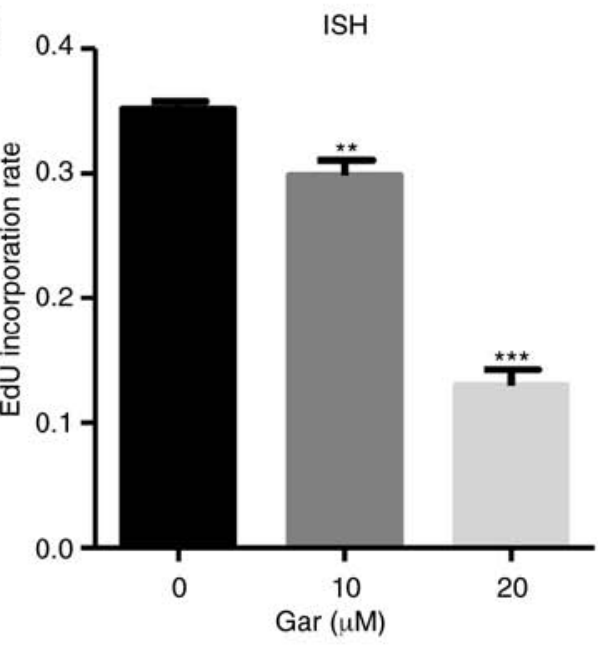

B
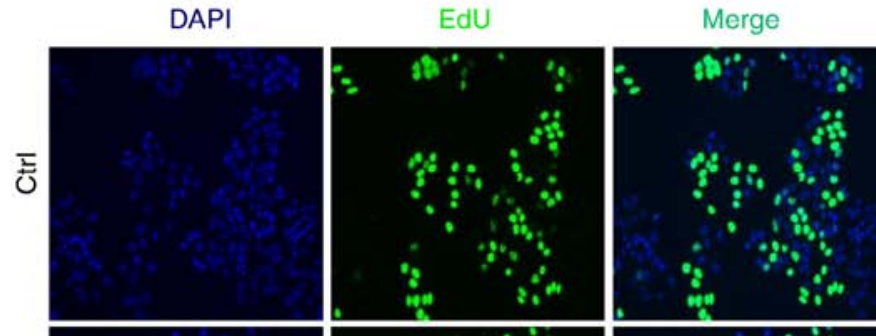

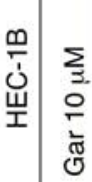
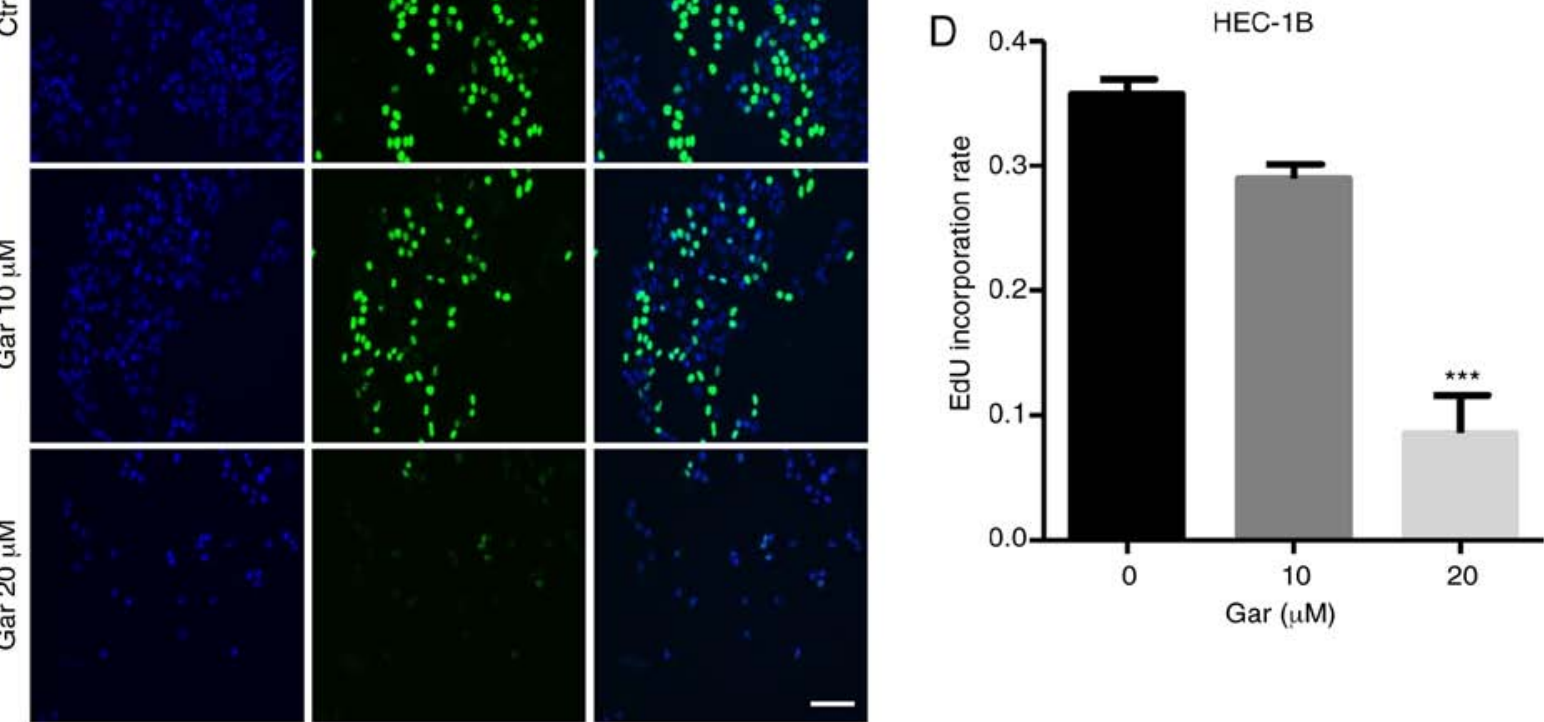

Figure 3. Garcinol inhibits EdU incorporation in EC cells. (A and B) The EdU incorporation assay was performed in ISH and HEC-1B cell lines for $48 \mathrm{~h}$ after 0, 10, and $20 \mu \mathrm{M}$ garcinol treatment. Scale bar, $100 \mu \mathrm{m}$. (C and D) The EdU incorporation rates of (C) ISH and (D) HEC-1B cells. Data are presented as the mean $\pm \mathrm{SD}, \mathrm{n}=3 .{ }^{* * *} \mathrm{P}<0.01$ and ${ }^{* * * *} \mathrm{P}<0.001$ as compared with the control, indicate statistical significance by one-way ANOVA with Dunnett's multiple comparisons test. EdU, 5-ethynyl-2'-deoxyuridine; EC, endometrial cancer; ISH, Ishikawa; Gar, garcinol.

Garcinol attenuates $S$-phase DNA synthesis in EC cells. To further assess the anti-proliferation function of garcinol, an EdU incorporation assay was used to directly detect DNA replication. After garcinol treatment, the percentage of EdU-positive cells was significantly decreased in the 10 and $20 \mu \mathrm{M}$ garcinol-treated ISH cells and $20 \mu \mathrm{M}$ HEC-1B cells compared with the control of both types of EC cells (Fig. 3). The result demonstrated that garcinol can attenuate S-phase DNA synthesis in EC cells to exert its anticancer effect.
Garcinol induces cell cycle arrest in ISH and HEC-1B cells. The cell cycle is an important physiological process which controls proliferation, growth and survival of cells. Cell cycle arrest can inhibit cancer cell proliferation, thus numerous anticancer drugs use this mechanism for cancer therapy $(20,27)$. After garcinol treatment for $48 \mathrm{~h}$, ISH cells were arrested in the G1 phase, while HEC-1B cells were arrested in the G2 phase, and garcinol reduced the number of cells in the $S$ phase in both cell types (Fig. 4). The cell cycle results indicated that garcinol 

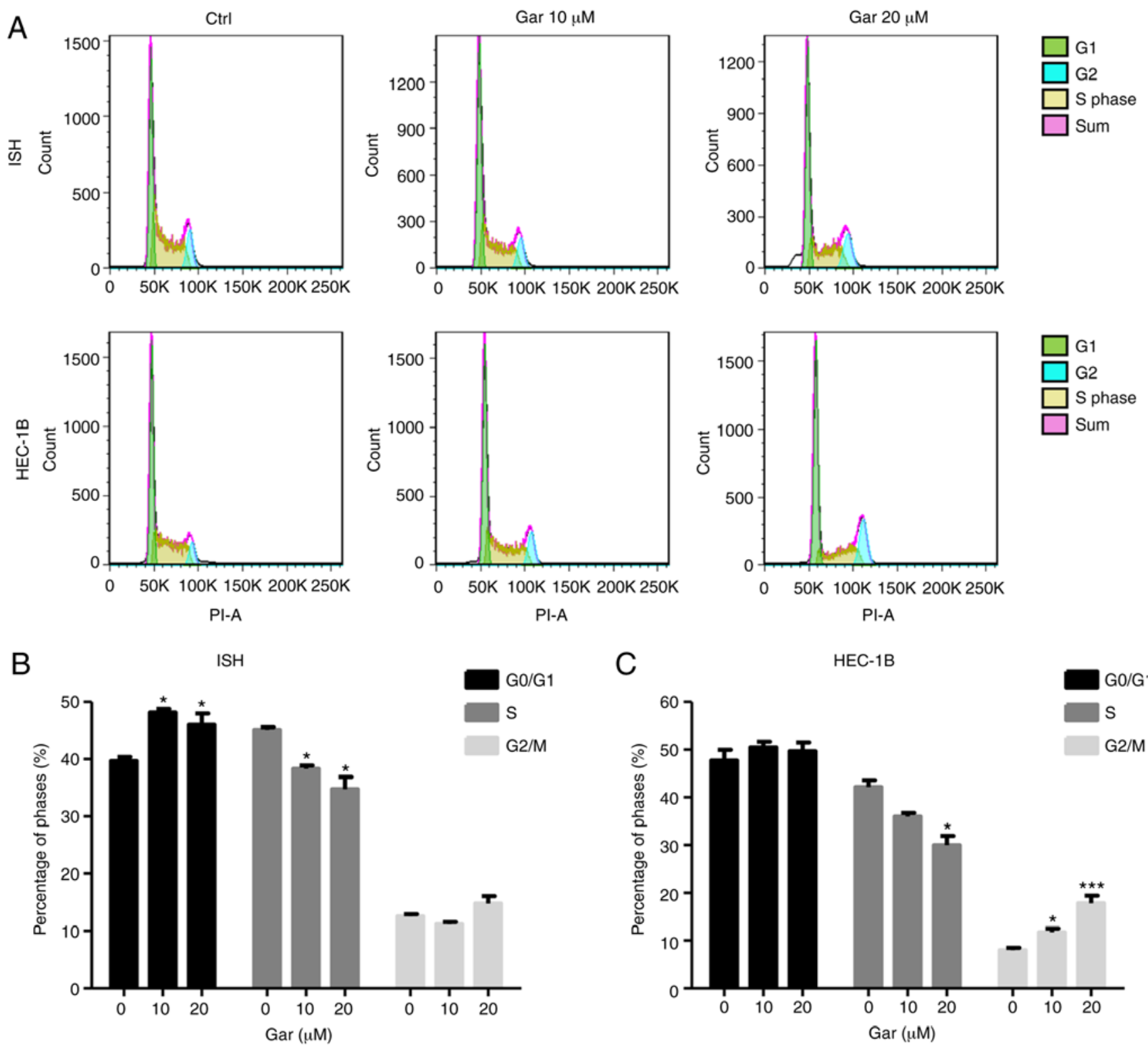

Figure 4. Garcinol induces cell cycle arrest in EC cells. (A) Cell cycle distribution in ISH and HEC-1B cells was assessed by flow cytometry after 0,10 and $20 \mu \mathrm{M}$ garcinol treatment for $48 \mathrm{~h}$. The percentage of cells in each phase for (B) ISH and (C) HEC-1B cells. Data are presented as the mean $\pm \mathrm{SD}, \mathrm{n}=3$. ${ }^{*} \mathrm{P}<0.05$ and ${ }^{* * *} \mathrm{P}<0.001$ compared with the control, indicate statistical significance by one-way ANOVA with Dunnett's multiple comparisons test. EC, endometrial cancer; ISH, Ishikawa; Gar, garcinol.

can inhibit cell proliferation by inducing cell cycle arrest in $\mathrm{EC}$, although the exact mechanism may differ for different EC cell types.

Garcinol regulates the expression of cell cycle-related genes in EC cells. Cell cycle progression is tightly controlled by cell cycle-related genes $(22,28)$. Therefore, examining the expression of those genes/proteins may elucidate how garcinol regulates the cell cycle in EC cells. Western blotting demonstrated that the expression of p53 and p21 was significantly increased, while the expression of CDK2, CDK4, cyclin D1 and cyclin B1 (22) was gradually decreased in a dose-dependent manner in both ISH and HEC-1B cell lines (Fig. 5). Moreover, p53 expression was more sensitive than the other genes to garcinol stimulation in ISH cells, and even $1 \mu \mathrm{M}$ garcinol could induce its expression. Therefore, garcinol could induce cell cycle arrest through regulating the expression of cell cycle-related proteins in EC cells.

Garcinol may activate the JNK/c-JUN signaling pathway in EC cells. The MAPK signaling pathway is a one of the key pathways regulating cell proliferation, the cell cycle and apoptosis. In the present study, ISH and HEC-1B cells were treated with $20 \mu \mathrm{M}$ garcinol for 30,60, 90 and $120 \mathrm{~min}$, and phosphorylation levels of JNK and c-JUN were detected by western blotting. Garcinol treatment increased phosphorylation levels of JNK and c-JUN, in both of ISH and HEC-1B cells (Fig. 6). p-JNK was significantly increased at 60 and $90 \mathrm{~min}$ in ISH cells, while it was significantly increased at 30, 90 and $120 \mathrm{~min}$ in HEC-1B cells. p-c-JUN was significantly increased at 90 and $120 \mathrm{~min}$ in ISH cells, and for HEC-1B cells, it was significantly increased from 30 to $120 \mathrm{~min}$. Therefore, 
A

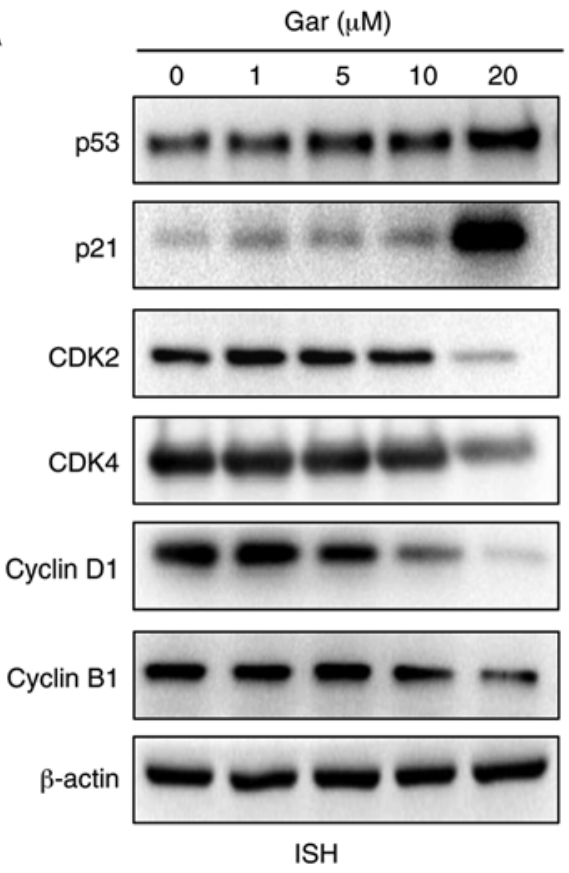

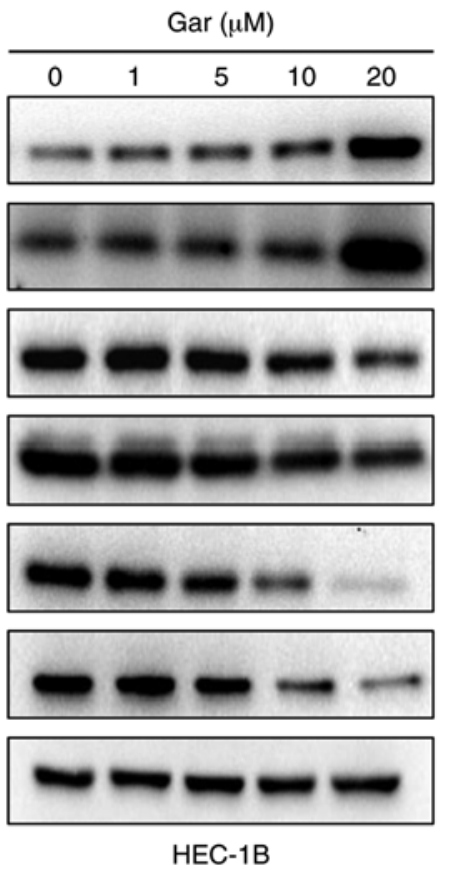

B
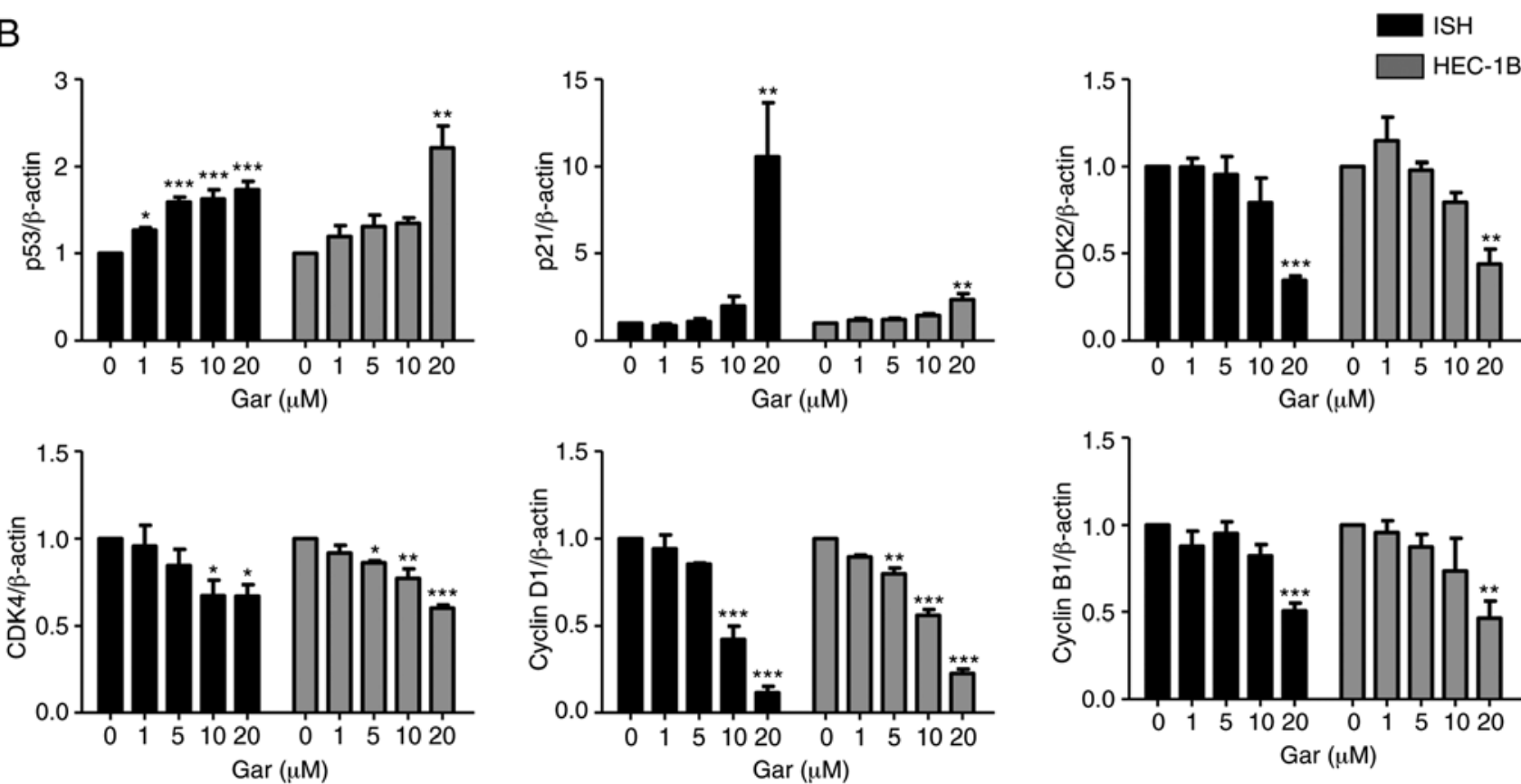

Figure 5. Garcinol regulates the expression of cell cycle-related proteins in EC cells. Effect of garcinol on the expression of cell cycle-regulated genes in EC cells were detected by western blotting. ISH and HEC-1B cells were cultured for $24 \mathrm{~h}$ and then treated with and without garcinol $(0,1,5,10$ and $20 \mu \mathrm{M})$ for another $24 \mathrm{~h}$. (A) Total protein was collected, and western blot analyses were performed for p53, p21, cyclin D1, cyclin B1, CDK2, CDK4. $\beta$-actin was used as $\alpha$ loading control. (B) Band density was analyzed by ImageJ, and the results are expressed as the mean $\pm \mathrm{SD}, \mathrm{n}=3 .{ }^{*} \mathrm{P}<0.05,{ }^{* * *} \mathrm{P}<0.01$ and ${ }^{* * *} \mathrm{P}<0.001 \mathrm{compared}$ with the control, indicate statistical significance by one-way ANOVA with Dunnett's multiple comparisons test. EC, endometrial cancer; ISH, Ishikawa; Gar, garcinol.

garcinol may increase JNK/c-JUN signaling to regulate the cell cycle in EC.

\section{Discussion}

EC is the most common cancer of the female reproductive system and an important cause of cancer-related deaths in women worldwide (29). The incidence and mortality of EC are increasing rapidly worldwide (30). The 5-year survival rate is more than $90 \%$ in patients with early-stage disease, treated with surgery and then brachytherapy or external beam radiation therapy $(29,31)$. However, the prognosis of patients with distant metastasis is poor, with the 5-year survival rate less than 20\% (32). The standard treatment for EC is surgery, and platinum-based chemotherapy and radiotherapy are recommended as adjuvant therapy for patients with high histological grade or metastasis (3). However, it is becoming increasingly important to develop new anticancer drugs. Previous studies 
A

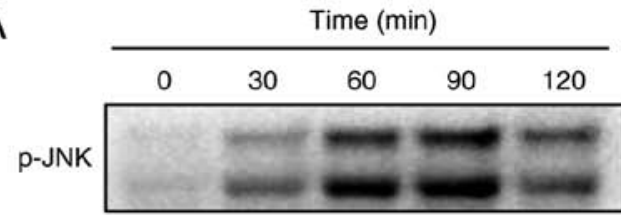

JNK

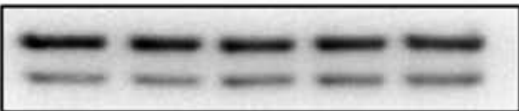

p-c-JUN

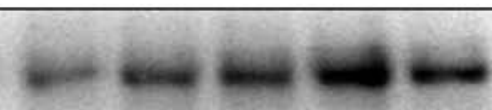

C-JUN

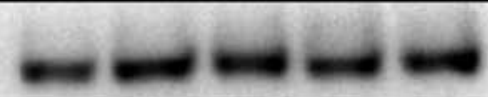

$\beta$-actin

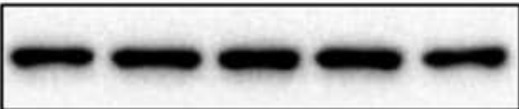

$\mathrm{ISH}$
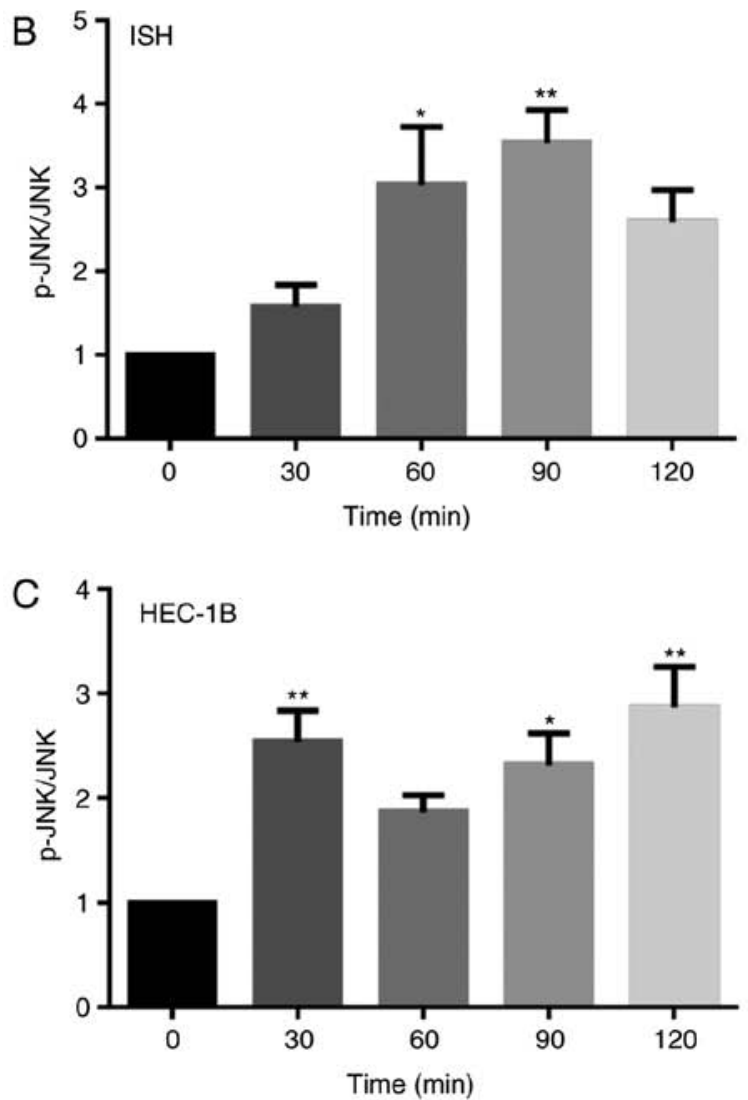
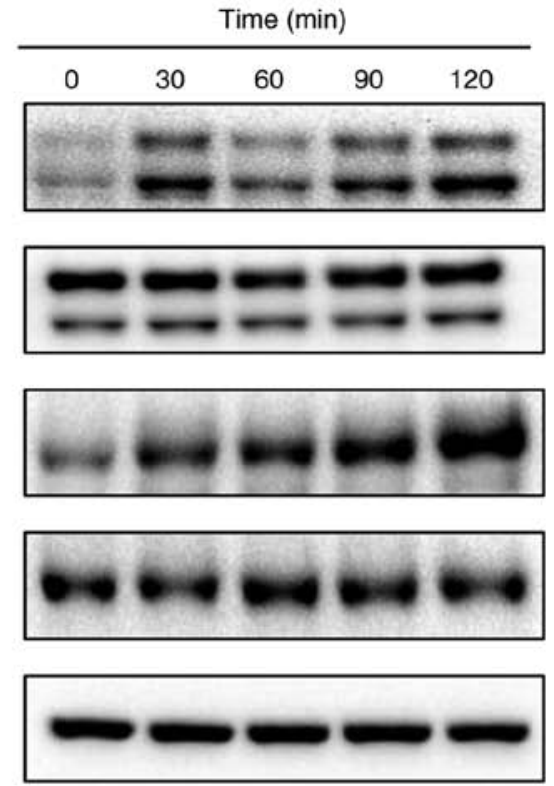

HEC-1B
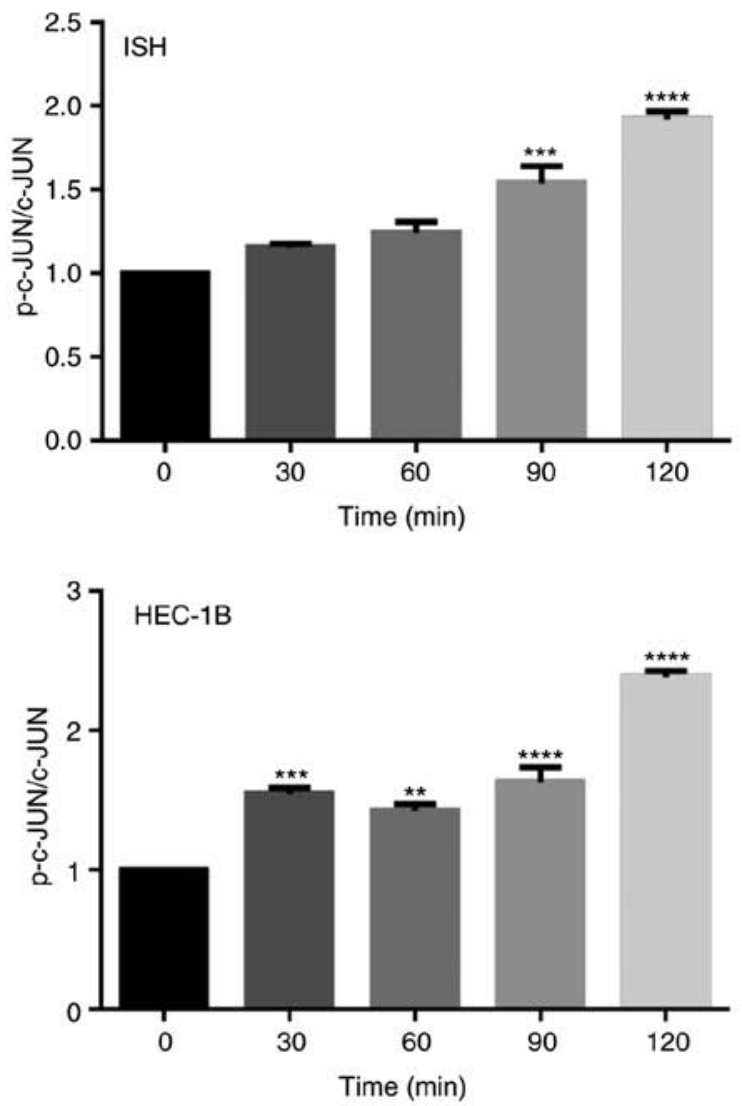

Figure 6. Garcinol activates the JNK/c-JUN signaling pathway in EC cells. (A) The effect of garcinol on JNK and c-JUN expression, and their phosphorylation levels in EC cells. ISH and HEC-1B cell were treated with garcinol $(20 \mu \mathrm{M})$ for 0, 30, 60, 90 and $120 \mathrm{~min}$. Western blot analyses were performed with anti-p-JNK, JNK, p-c-JUN and c-JUN antibodies. $\beta$-actin was used as a loading control. (B and C) Band density was analyzed by ImageJ, and the results are expressed as the mean $\pm \mathrm{SD}, \mathrm{n}=3 .{ }^{*} \mathrm{P}<0.05,{ }^{* * *} \mathrm{P}<0.01,{ }^{* * * *} \mathrm{P}<0.001$ and ${ }^{* * * * *} \mathrm{P}<0.0001$ compared with the control, indicate statistical significance by one-way ANOVA with Dunnett's multiple comparisons test. JNK, c-JUN N-terminal kinase; EC, endometrial cancer; ISH, Ishikawa; Gar, garcinol.

indicated that garcinol could inhibit cancer cell proliferation and induce cell cycle arrest and apoptosis $(12,24,26)$. In the present study, it was demonstrated that garcinol could inhibit the proliferation and cell cycle progression of ISH and HEC-1B cells.
The cell cycle has three important checkpoints G1-to-S, G2-to-M and M-to-G1. However, cell cycle arrest at any point will finally lead to diminished cell proliferation. In cancer cells, minimal blocks at the G1-S transition point drives cells into the $\mathrm{S}$ phase, resulting in uncontrolled growth, therefore 
investigation of agents which target the cell cycle is a viable option for therapeutics (28). Several previous studies have also reported that garcinol treatment arrested the cell cycle at the G0/G1 phase in breast cancer MCF-7 cells, lung cancer cells, and cervical cancer cells $(17,19,26,33)$. Garcinol has also been revealed to arrest oral cancer cells at the $S$ phase (24), and 3T3-L1 cells at the G2/M phase (34). The present study also revealed that garcinol caused cell cycle arrest in EC, although its effect was different in the two different cell lines investigated. ISH cells were arrested at the G1 phase and HEC-1B cells were arrested at the G2 phase, although both cell types had a decrease in the number of cells in the $\mathrm{S}$ phase, which corresponded to a decrease in S-phase DNA synthesis. The differences in mechanism of cell cycle arrest between these two cell types may be determined by their variant genetic characteristics. The ISH cell line is derived from a well differentiated adenocarcinoma, with high expression levels of ER- $\alpha$, ER- $\beta$ and PR, but low expression levels of hMLH- 1 and PTEN (35). The HEC-1B cell line is derived from a moderately differentiated adenocarcinoma, with low expression levels of ER- $\alpha$, ER- $\beta$ and PR, but high expression levels of hMLH- 1 and PTEN (35). However, whether these genetic differences have effects, or how they are involved in the effects of garcinol in EC remain to be further investigated. These studies all support that garcinol decreases cancer cell proliferation by targeting the cell cycle, although the exact mode of action may differ depending on the cancer cell type.

The progression of the cell cycle is regulated by cyclins and CDK complexes. CDKs are activated by cyclins and suppressed by cyclin-dependent kinase inhibitors at cell cycle checkpoints or specific phases $(20,22)$. Garcinol has been revealed to inhibit cervical cancer cell cycle progression at the G0/G1 phase, via a mechanism associated with downregulation of cyclin D1 and CDK4, and upregulation of p21 and p53 (19). In lung cancer cells, garcinol treatment downregulated the expression of CDK2, CDK4 and cyclin D, leading to the H1299 lung cancer cells being arrested at the G1 phase (26). In the present study it was demonstrated that garcinol treatment upregulated the expression of the tumor suppressor proteins p53 and p21, and downregulated the expression of their target proteins CDK4, cyclin D1 and cyclin B1 in ISH and HEC-1B cells. However, garcinol arrested the cell cycle at different points in these two cell lines suggesting some other, as yet unidentified, pathways may also be involved in garcinol cell cycle arrest in different EC cell lines.

The mitogen-activated protein kinase (MAPK) signaling pathway is an important pathway in cancer, and has been developed as a target for cancer treatment. It is known that JNK, ERK and p38 are all members of the MAPK pathway which are involved in cell proliferation, differentiation, cell cycle and apoptosis (25). Numerous anticancer drugs exert their effects through the p38 MAPK or ERK/MAPK signaling pathways to control cell proliferation $(23,25,26,36)$. c-JUN is the major downstream target of JNK signaling, and transcriptional regulation of c-JUN and its target genes is one of the main functions of JNK (37). The MAPK signaling pathway has been reported to play a role in various types of cancer including prostate, colorectal and pancreatic cancers and has been developed as a therapeutic target (38). The present study revealed that after garcinol treatment the expression of p53, a downstream target of the JNK/c-JUN pathway, was increased in EC. Therefore, it was determined whether garcinol inhibited EC cell proliferation through the JNK/c-JUN signaling pathway. As a cell permeable drug, garcinol may affect signaling pathways in cells to regulate the proliferation and the cell cycle in EC cells. Garcinol increased phosphorylation of both JNK and c-JUN in both EC cell types investigated. The regulation of the JNK signaling pathway may be one of the signaling mechanisms by which garcinol inhibits proliferation of EC. The activation of p-JNK has also been found in response to other anticancer agents such as huaier, aplidin and adaphostin $(25,37,39,40)$. JNK in turn can phosphorylate and activate the transcription factor activator protein-1 (AP-1), and activating transcription factor-2, c-Myc, p53, and Bcl-2 family proteins, with these proteins controlling various cellular responses, such as proliferation, differentiation, apoptosis, the cell cycle and autophagy $(25,37,39,40)$. Since the JNK/c-JUN pathway was activated and its downstream target gene p53 was significantly increased after garcinol treatment, the JNK/c-JUN pathway may play important roles in garcinol-induced EC cell cycle arrest. However, it is also possible that other pathways may also be involved.

As a tumor suppressor gene, p53 induces cell cycle arrest mainly through transcriptional activation of $\mathrm{p} 21$, which in turn binds to cyclin D/CDK4 complexes and may cause G1 phase arrest $(41,42)$. Garcinol treatment induced H1299 lung cancer cell $\mathrm{G} 1$ arrest through $\mathrm{p} 21^{\text {Waf1/Cip1 }}$ and $\mathrm{p} 27^{\mathrm{Kip} 1}$ activation, and subsequent inhibition of CDK activity (26). p53 acts mainly through the transcriptional activation of p21, and p21 binding to cyclin D/CDK4 complexes to cause G1 phase arrest (42). Therefore, it was demonstrated that garcinol may act by upregulating the expression of p21 and p53 and downregulating cyclin D1 and CDK4 to induce ISH cell arrest in the G1/S phase. However, p53 activation can not only arrest cells at the G0/G1 checkpoint, but also at the G2/M checkpoint, because p21 can also inhibit cyclin $\mathrm{B} / \mathrm{CDK} 1$ to inhibit cell-cycle progression, and other p53 target genes such as 14-3-30 GADD45, may interrupt the interaction of $\mathrm{Cdc} 2 /$ cyclin $\mathrm{B} 1$ and participate in the arrest of $\mathrm{G} 2 / \mathrm{M}$ transition $(43,44)$. In the present study it was demonstrated that the expression of cyclin B1 was reduced, fitting with cell cycle arrest in the $\mathrm{G} 2 / \mathrm{M}$ phase in HEC-1B cells induced by garcinol. Therefore, garcinol may act through activation of p53, upregulation of p21 leading to inhibition of cyclin B1 and finally causing HEC-1B cell arrest in the $\mathrm{G} 2 / \mathrm{M}$ phase.

Previous studies have suggested that garcinol could inhibit cancer cell proliferation through inhibition of STAT-3, NF- $\kappa$ B and PI3K/AKT signaling pathways $(16,19,24)$. However, in the present study, one of the limitations was that we only investigated the role of garcinol in the JNK/c-JUN pathway in EC. In addition, garcinol is an inhibitor of the histone acetyltransferases (HAT) p300 and Pcaf (45), with numerous roles in neurocytes $(46-49)$, immunocytes $(50,51)$ and cancer cells. Therefore, further in vitro studies should also investigate other potential signaling pathways, as well as other potential targets of garcinol activity including apoptosis, autophagy and invasion. To further verify the potential use of garcinol as a therapeutic for EC its effects on primary EC cells should also be investigated in vitro, as well as in in vivo animal models, particularly focusing on metastatic disease. 
In conclusion, in the present study evidence was provided that garcinol can inhibit cell growth and induce cell cycle arrest in EC, by regulating the expression of cell cycle-related genes and the JNK/c-JUN signaling pathway. Therefore, garcinol may be a promising candidate agent for EC chemotherapy.

\section{Acknowledgements}

We appreciate Mrs. Shang Wang and Mr. Xiaobin Liu at Guangzhou Women and Children's Medical Center (Guangzhou, China) for their assistance with flow cytometry and fluorescence microscopy, respectively.

\section{Funding}

The present study was supported by the National Natural Science Foundation of China (grant nos. 81702567, 81671406 and 31871412), the Science and Technology Programs of Guangzhou City (grant no. 201704030103), the Post-doc Initiation Fund of Guangzhou (grant no. 3302), and the Post-doc Science Research Initiation Fund of Guangzhou Women and Children's Medical Center (grant no. 20160322).

\section{Availability of data and materials}

The datasets used during the present study are available from the corresponding author upon reasonable request.

\section{Authors' contributions}

MZ and QL performed the cell culture, cell counting assays and flow cytometric analysis. MZ performed the RTCA and EdU assays. MZ, HH, DS, MC, FN, PW, YD, YP, and DW performed the western blot experiments. MZ, QL and GEL designed the study and performed the analyses. MZ and QL wrote the manuscript and GEL revised the manuscript. All authors read and approved the manuscript and agree to be accountable for all aspects of the research in ensuring that the accuracy or integrity of any part of the work are appropriately investigated and resolved.

\section{Ethics approval and consent to participate}

Not applicable.

\section{Patient consent for publication}

Not applicable.

\section{Competing interests}

The authors declare that they have no competing interests.

\section{References}

1. Lee YC, Lheureux S and Oza AM: Treatment strategies for endometrial cancer: Current practice and perspective. Curr Opin Obstet Gynecol 29: 47-58, 2017.

2. Sorosky JI: Endometrial cancer. Obstet Gynecol 120: 383-397, 2012.
3. Mitamura T, Dong $\mathrm{P}$, Ihira $\mathrm{K}$, Kudo $\mathrm{M}$ and Watari $\mathrm{H}$ : Molecular-targeted therapies and precision medicine for endometrial cancer. Jpn J Clin Oncol 49: 108-120, 2019.

4. Oza AM, Elit L, Tsao MS, Kamel-Reid S, Biagi J, Provencher DM, Gotlieb WH, Hoskins PJ, Ghatage P, Tonkin KS, et al: Phase II study of temsirolimus in women with recurrent or metastatic endometrial cancer: A trial of the NCIC clinical trials group. J Clin Oncol 29: 3278-3285, 2011.

5. Ushijima K: Hormonal treatment of endometrial cancer. Nihon Rinsho 70 (Suppl 4): 388-393, 2012 (In Japanese).

6. Ito K, Utsunomiya $\mathrm{H}$, Niikura $\mathrm{H}$, Yaegashi $\mathrm{N}$ and Sasano $\mathrm{H}$ : Inhibition of estrogen actions in human gynecological malignancies: New aspects of endocrine therapy for endometrial cancer and ovarian cancer. Mol Cell Endocrinol 340: 161-167, 2011.

7. Miller KD, Fidler-Benaoudia M, Keegan TH, Hipp HS, Jemal A and Siegel RL: Cancer statistics for adolescents and young adults, 2020. CA Cancer J Clin: 17 Sep 17, 2020 (Epub ahead of print. doi.org/10.3322/caac.21637 2020

8. Lindemann K, Eskild A, Vatten LJ and Bray F: Endometrial cancer incidence trends in norway during 1953-2007 and predictions for 2008-2027. Int J Cancer 127: 2661-2668, 2010.

9. Sung H, Siegel RL, Rosenberg PS and Jemal A: Emerging cancer trends among young adults in the USA: Analysis of a population-based cancer registry. Lancet Public Health 4: e137-e147, 2019.

10. Jayaprakasha GK and Sakariah KK: Determination of organic acids in leaves and rinds of Garcinia indica (Desr.) by LC. J Pharm Biomed Anal 28: 379-384, 2002.

11. Schobert R and Biersack B: Chemical and biological aspects of garcinol and isogarcinol: Recent developments. Chem Biodivers 16: e1900366, 2019.

12. Liu C, Ho PC, Wong FC, Sethi G, Wang LZ and Goh BC: Garcinol: Current status of its anti-oxidative, anti-inflammatory and anti-cancer effects. Cancer Lett 362: 8-14, 2015.

13. Saadat N and Gupta SV: Potential role of garcinol as an anticancer agent. J Oncol 2012: 647206, 2012.

14. Padhye S, Ahmad A, Oswal N and Sarkar FH: Emerging role of Garcinol, the antioxidant chalcone from Garcinia indica Choisy and its synthetic analogs. J Hematol Oncol 2: 38, 2009.

15. Wang L, Wang M, Guo $\mathrm{H}$ and Zhao $\mathrm{H}$ : Emerging role of garcinol in targeting cancer stem cells of non-small cell lung cancer. Curr Pharmacol Rep 5: 14-19, 2019.

16. Ahmad A, Sarkar SH, Aboukameel A, Ali S, Biersack B, Seibt S, Li Y, Bao B, Kong D, Banerjee S, et al: Anticancer action of garcinol in vitro and in vivo is in part mediated through inhibition of STAT-3 signaling. Carcinogenesis 33: 2450-2456, 2012.

17. Ye X, Yuan L, Zhang L, Zhao J, Zhang CM and Deng HY: Garcinol, an acetyltransferase inhibitor, suppresses proliferation of breast cancer cell line MCF-7 promoted by $17 \beta$-estradiol. Asian Pac J Cancer Prev 15: 5001-5007, 2014.

18. Wang J, Wu M, Zheng D, Zhang H, Lv Y, Zhang L, Tan HS, Zhou H, Lao YZ and Xu HX: Garcinol inhibits esophageal cancer metastasis by suppressing the $\mathrm{p} 300$ and TGF- $\beta 1$ signaling pathways. Acta Pharmacol Sin 41: 82-92, 2020.

19. Zhao J, Yang T, Ji J, Li C, Li Z and Li L: Garcinol exerts anti-cancer effect in human cervical cancer cells through upregulation of T-cadherin. Biomed Pharmacother 107: 957-966, 2018.

20. Malumbres M and Barbacid M: Cell cycle, CDKs and cancer: A changing paradigm. Nat Rev Cancer 9: 153-166, 2009.

21. Malumbres $\mathbf{M}$ and Barbacid M: Mammalian cyclin-dependent kinases. Trends Biochem Sci 30: 630-641, 2005.

22. Massagué J: G1 cell-cycle control and cancer. Nature 432: 298-306, 2004.

23. Ryu M, Sung CK, Im YJ and Chun C: Activation of JNK and p38 in MCF-7 cells and the in vitro anticancer activity of alnus hirsuta extract. Molecules 25: 1073, 2020.

24. Aggarwal S and Das SN: Garcinol inhibits tumour cell proliferation, angiogenesis, cell cycle progression and induces apoptosis via NF-кB inhibition in oral cancer. Tumour Biol 37: 7175-7184, 2016.

25. Yan L, Liu X, Yin A, Wei Y, Yang Q and Kong B: Huaier aqueous extract inhibits cervical cancer cell proliferation via JNK/p38 pathway. Int J Oncol 47: 1054-1060, 2015.

26. Yu SY, Liao CH, Chien MH, Tsai TY, Lin JK and Weng MS: Induction of $\mathrm{p} 21$ (Waf1/Cip1) by garcinol via downregulation of p38-MAPK signaling in p53-independent H1299 lung cancer. J Agric Food Chem 62: 2085-2095, 2014.

27. George VC, Kumar DR and Kumar RA: Relative in vitro potentials of parthenolide to induce apoptosis and cell cycle arrest in skin cancer cells. Curr Drug Discov Technol 13: 34-40, 2016. 
28. Bertoli C, Skotheim JM and de Bruin RA: Control of cell cycle transcription during G1 and S phases. Nat Rev Mol Cell Biol 14: 518-528, 2013.

29. Giannone G, Tuninetti V, Ghisoni E, Genta S, Scotto G, Mittica G and Valabrega G: Role of cyclin-dependent kinase inhibitors in endometrial cancer. Int J Mol Sci 20: 2353, 2019.

30. Cai Z and Liu Q: Understanding the global cancer statistics 2018 : Implications for cancer control. Sci China Life Sci: Aug 26, 2019 (Epub ahead of print). doi: 10.1007/s11427-019-9816-1.

31. Signorelli M, Lissoni AA, Cormio G, Katsaros D, Pellegrino A, Selvaggi L, Ghezzi F, Scambia G, Zola P, Grassi R, et al: Modified radical hysterectomy versus extrafascial hysterectomy in the treatment of stage I endometrial cancer: Results from the ILIADE randomized study. Ann Surg Oncol 16: 3431-3441, 2009.

32. Dowdy SC: Improving oncologic outcomes for women with endometrial cancer: Realigning our sights. Gynecol Oncol 133: 370-374, 2014.

33. Collins HM, Abdelghany MK, Messmer M, Yue B, Deeves SE Kindle KB, Mantelingu K, Aslam A, Winkler GS, Kundu TK and Heery DM: Differential effects of garcinol and curcumin on histone and p53 modifications in tumour cells. BMC Cancer 13: 37, 2013.

34. Hsu CL, Lin YJ, Ho CT and Yen GC: Inhibitory effects of garcinol and pterostilbene on cell proliferation and adipogenesis in 3T3-L1 cells. Food Funct 3: 49-57, 2012.

35. Qu W, Zhao Y, Wang X, Qi Y, Zhou C, Hua Y, Hou J and Jiang SW: Culture characters, genetic background, estrogen/progesterone receptor expression, and tumorigenic activities of frequently used sixteen endometrial cancer cell lines. Clin Chim Acta 489: 225-232, 2019.

36. Lim W, Jeong M, Bazer FW and Song G: Coumestrol inhibits proliferation and migration of prostate cancer cells by regulating AKT, ERK1/2, and JNK MAPK cell signaling cascades. J Cell Physiol 232: 862-871, 2017.

37. Kumar A, Singh UK, Kini SG, Garg V, Agrawal S, Tomar PK, Pathak P, Chaudhary A, Gupta P and Malik A: JNK pathway signaling: A novel and smarter therapeutic targets for various biological diseases. Future Med Chem 7: 2065-2086, 2015

38. Sebolt-Leopold JS and Herrera R: Targeting the mitogen-activated protein kinase cascade to treat cancer. Nat Rev Cancer 4 : 937-947, 2004

39. Cuadrado A, Garcia-Fernandez LF, Gonzalez L, Suarez Y, Losada A, Alcaide V, Martinez T, Fernandez-Sousa JM, Sanchez-Puelles JM and Munoz A: Aplidin induces apoptosis in human cancer cells via glutathione depletion and sustained activation of the epidermal growth factor receptor, Src, JNK, and p38 MAPK. J Biol Chem 278: 241-250, 2003.
40. Yu C, Rahmani M, Almenara J, Sausville EA, Dent P and Grant S: Induction of apoptosis in human leukemia cells by the tyrosine kinase inhibitor adaphostin proceeds through a RAF-1/MEK/ERK- and AKT-dependent process. Oncogene 23: 1364-1376, 2004.

41. Harvey M, Sands AT, Weiss RS, Hegi ME, Wiseman RW,Pantazis P, Giovanella BC, Tainsky MA, Bradley A and Donehower LA: In vitro growth characteristics of embryo fibroblasts isolated from p53-deficient mice. Oncogene 8: 2457-2467, 1993.

42. Chen J: The cell-cycle arrest and apoptotic functions of p53 in tumor initiation and progression. Cold Spring Harb Perspect Med 6: a026104, 2016.

43. Martín-Caballero J, Flores JM, García-Palencia P and Serrano M: Tumor susceptibility of p21(Waf1/Cip1)-deficient mice. Cancer Res 61: 6234-6238, 2001.

44. Taylor WR and Stark GR: Regulation of the G2/M transition by p53. Oncogene 20: 1803-1815, 2001.

45. Balasubramanyam K, Altaf M, Varier RA, Swaminathan V, Ravindran A, Sadhale PP and Kundu TK: Polyisoprenylated benzophenone, garcinol, a natural histone acetyltransferase inhibitor, represses chromatin transcription and alters global gene expression. J Biol Chem 279: 33716-33726, 2004.

46. Wang YW, Zhang X, Chen CL, Liu QZ, Xu JW, Qian QQ, Li WY and Qian YN: Protective effects of Garcinol against neuropathic pain-evidence from in vivo and in vitro studies. Neurosci Lett 647: 85-90, 2017.

47. Dunbar AB and Taylor JR: Garcinol blocks the reconsolidation of multiple cocaine-paired cues after a single cocaine-reactivation session. Neuropsychopharmacology 42: 1884-1892, 2017.

48. Hao F, Jia LH, Li XW, Zhang YR and Liu XW: Garcinol upregulates GABAA and GAD65 expression, modulates BDNF-TrkB pathway to reduce seizures in pentylenetetrazole (PTZ)-induced epilepsy. Med Sci Monit 22: 4415-4425, 2016.

49. Weng MS, Liao CH, Yu SY and Lin JK: Garcinol promotes neurogenesis in rat cortical progenitor cells through the duration of extracellular signal-regulated kinase signaling. J Agric Food Chem 59: 1031-1040, 2011.

50. Li W, Li H, Zhang M, Zhong Y, Wang M, Cen J, Wu H, Yang Y and Wei Q: Isogarcinol extracted from Garcinia mangostana $\mathrm{L}$. ameliorates systemic lupus erythematosus-like disease in a murine model. J Agric Food Chem 63: 8452-8459, 2015.

51. Cui ZL, Gu W, Ding T, Peng XH, Chen X, Luan CY, Han RC, $\mathrm{Xu}$ WG and Guo XJ: Histone modifications of Notch1 promoter affect lung CD4+ T cell differentiation in asthmatic rats. Int $\mathrm{J}$ Immunopathol Pharmacol 26: 371-381, 2013.

(i) $\odot$ This work is licensed under a Creative Commons Attribution-NonCommercial-NoDerivatives 4.0 International (CC BY-NC-ND 4.0) License. 